\title{
Sea bream Sparus aurata, an asymptomatic contagious fish host for nodavirus
}

\author{
J. Castric ${ }^{1, *}$, R. Thiéry ${ }^{1}$, J. Jeffroy ${ }^{1}$, P. de Kinkelin ${ }^{2}$, J. C. Raymond ${ }^{3}$ \\ ${ }^{1}$ Afssa Site de Brest, BP 70, 29280 Plouzané, France \\ ${ }^{2}$ INRA, Unité de Virologie et d'Immunologie Moléculaires, Laboratoire de Pathologie Infectieuse et Immunité des Poissons, \\ 78352 Jouy-en-Josas cedex, France \\ ${ }^{3}$ SAVU-CNPMEM, Les Amandiers, Rue Berthe Morisot, 34430 St-Jean de Védas, France
}

\begin{abstract}
During an epidemiological survey of viral encephalopathy and retinopathy (VER) in diseased sea bass Dicentrarchus labrax, a nodavirus isolate was recovered from net pen-reared sea bream Sparus aurata harboured in the same farming premises. After the virus was isolated and identified by immunofluorescence on SSN-1 cells, sequence analysis with a PCR product from the T4 region of the capsid protein gene indicated that the virus shared $100 \%$ identity with a pathogenic virus strain isolated from sea bass. Infection trials demonstrated the pathogenicity of the sea bream virus isolate for juvenile sea bass whereas sea bream infected with the same virus isolate remained asymptomatic even following intramuscular injection of virus. Nevertheless, the sea bream appeared to be a potential carrier of nodavirus, as juvenile sea bass became infected when maintained in a tank containing experimentally contaminated sea bream.
\end{abstract}

KEY WORDS: Nodavirus · Sea bream · Sea bass · Polymerase chain reaction · Sequencing · Virulence Resale or republication not permitted without written consent of the publisher

\section{INTRODUCTION}

Nodaviruses are the agents of viral encephalopathy and retinopathy (VER) of fish. The disease also called viral nervous necrosis (VNN) or fish encephalitis (Mori et al. 1992, Comps et al. 1994) is responsible for severe losses in many species of marine farmed fish throughout the world. More than 20 species of finfish have been reported to be affected by these neurotropic viruses (Muroga 1995, Nakai et al. 1995, Sweetman et al. 1996, Munday \& Nakai 1997).

Piscine nodaviruses are non-enveloped virions of about $25 \mathrm{~nm}$ in diameter. Their genome consists of 2 single-stranded positive-sense RNA molecules with respective molecular weights of $1.01 \times 10^{6} \mathrm{Da}$ for $\mathrm{Rna}_{1}$ and $0.49 \times 10^{6} \mathrm{DA}$ for $\mathrm{RNA}_{2}$ (Mori et al. 1992).

The transmission of fish nodaviruses can occur vertically from spawners to larvae through the eggs or gen-

*E-mail: j.castric@brest.afssa.fr ital fluids as reported for striped jack Pseudocaranx dentex (Arimoto et al. 1992, Mushiake et al. 1994, Nishizawa et al. 1996). The horizontal route of transmission has been experimentally demonstrated by placing healthy fish in contact with diseased larvae (Arimoto et al. 1993), by bathing fish in water contaminated by addition of nodavirus-infected tissue homogenates (Glazebrook et al. 1990, Arimoto et al. 1993, Tanaka et al. 1998, Grotmol et al. 1999), by addition of virus purified from diseased fish (Nguyen et al. 1996), or by addition of nodavirus produced in SSN-1 cells (Péducasse et al. 1999).

Horizontal transmission of nodavirus by asymptomatic carriers has been suggested in sea bass by Le Breton et al. (1997b), and by Skliris \& Richards (1999), who demonstrated the presence of virus in healthy tilapia Oreochromis mossambicus undergoing experimental infection with the virus. Similarly, the presence of diseased wild fish species such as groupers in the vicinity may constitute a serious risk for farmed fish (Le Breton et al. 1997a). 
However, the VER status of the sea bream, a most promising species for the Mediterranean aquaculture industry, has not been documented thus far, although this fish has often been reared in the same sites as sea bass. Therefore, in order to assess if sea bream could be a potential carrier, shedding nodavirus under aquaculture conditions, healthy-looking sea bream were collected from a neighbouring floating cage containing sea bass which were experiencing a nodavirosis outbreak in a Mediterranean fish farm, and then processed for virological diagnosis.

We report here that a nodavirus isolate recovered from these healthy sea bream was highly pathogenic for sea bass, and we demonstrate that sea bream experimentally infected with this isolate did not show any clinical signs of nodavirosis but could transmit the virus to sea bass during cohabitation.

\section{MATERIAL AND METHODS}

Virological procedures. The SSN-1 cell line from Channa striatus (Frerichs et al. 1996) was used for virus assay and propagation. The cells were propagated at $29^{\circ} \mathrm{C}$ in Leibovitz medium $\left(\mathrm{L}_{15}\right)$ supplemented with $10 \%$ foetal bovine serum (FBS), L-glutamine (2 mM $\mathrm{ml}^{-1}$ ), penicillin (100 I.U. ml ${ }^{-1}$ ) and streptomycin (0.1 mg $\left.\mathrm{ml}^{-1}\right)$.

Ten sea bream weighing between 5 and $10 \mathrm{~g}$ were collected from 1 net pen and stored at $-20^{\circ} \mathrm{C}$. For tissue analysis, the fish were thawed and half of the brain and 1 eye from each fish were removed for homogenisation with a mortar and pestle and diluted to $10^{-1}$ in PBS containing 200 I.U. $\mathrm{ml}^{-1}$ of penicillin, $0.2 \mathrm{mg} \mathrm{ml}^{-1}$ of streptomycin, and $0.2 \mathrm{mg} \mathrm{ml}^{-1}$ kanamycin. The homogenate was then centrifuged at $3000 \times g$ for $15 \mathrm{~min}$ at $4^{\circ} \mathrm{C}$. The supernatant was diluted to $10^{-1}$ and $10^{-2}$ in $\mathrm{L}_{15}$ medium and duplicates of each dilution were inoculated onto SSN-1 cells which had been grown in a 24 -well plate for $48 \mathrm{~h}\left(100 \mu \mathrm{l}\right.$ well $\left.^{-1}\right)$. After inoculation, the cells were incubated at $24^{\circ} \mathrm{C}$ and regularly monitored for a cytopathic effect (CPE). Seven days later, a second passage was performed onto new SSN-1 cells. Virus detection and identification were performed by an indirect immunofluorescence antibody technique (IFAT). Briefly, $5 \mathrm{~d}$ after the second passage was performed, the cell supernatants were saved and the cell monolayers fixed using cold ethanol-acetone (7V/3V) for $15 \mathrm{~min}$, then rinsed 3 times in PBS-Tween 20 (0.05\%). Then $250 \mu \mathrm{l}$ of a diluted anti-nodavirus rabbit serum, raised against purified virions of a sea bass nodavirus isolate, were distributed into each well and the cells incubated for $1 \mathrm{~h}$ at $37^{\circ} \mathrm{C}$. The cells were then rinsed 3 times with PBS-Tween 20, and $250 \mu \mathrm{l}$ of a goat anti-rabbit immunoglobulin serum conjugated with fluorescein isothiocyanate (Sigma, St. Quentin, Fallavier, France) were added. After $1 \mathrm{~h}$ incubation at $37^{\circ} \mathrm{C}$, the cells were rinsed 3 times with PBS-Tween 20 and observed for fluorescence (Olympus TX50 inverted fluorescence microscope $[\times 200])$.

The viral titration was performed on SSN-1 cells grown in 24-well plates. The viral suspensions were diluted from $10^{-1}$ to $10^{-8}$, then 4 wells of a plate were inoculated with $50 \mu \mathrm{l}$ of each dilution. After $5 \mathrm{~d}$ incubation at $24^{\circ} \mathrm{C}$, the cells were fixed and the IFAT technique used to visualize nodavirus infected cells. The $50 \%$ tissue culture infective dose $\left(\mathrm{TCID}_{50}\right)$ was estimated by the end-point titration method (Kärber 1931).

Nodavirus detection by RT-PCR. The same healthy sea bream, which had no clinical signs of nodavirosis and which had been used for virological examination, were also processed for nodavirus detection by RTPCR. One eye and approximately half of the brain were sampled from each fish individually. Total RNA from each sample was extracted using RNA NOWTM (Biogentex, Seabrook, TX, USA), a reagent which is based on a modification of the Guanidinium saltPhenol-Chloroform method (Chomczinsky \& Sacchi 1987), according to the manufacturer's instructions.

Three microlitres of the total RNA samples were subjected to reverse transcription using Marine Leukemia Virus (MuLV) reverse transcriptase (Perkin Elmer, Courtaboeuf, France), followed by 40 cycles of PCR amplification using the primers (R3, F2) designed to amplify the T4 region of RNA2 from Striped Jack Nervous Necrosis Virus (SJNNV) and Ampli Taq DNA polymerase (Perkin Elmer). The sequence of the primers and the cycling conditions were the same as described (Nishizawa et al. 1994). Fifteen microliters of the PCR products were analysed by electrophoresis on a $2 \%$ agarose gel stained with ethidium bromide.

In order to improve the sensitivity of detection, nested RT-PCR was also performed on the same samples, using the procedure described previously (Thiéry et al. 1999b). In case of successful amplification, nested RT-PCR produced an amplicon of $294 \mathrm{bp}$.

Sequence analysis of PCR products. The sequence of the T4 region of the nodavirus capsid protein gene was determined using viral RNA from strain $\mathrm{V}_{113}$ isolated from 1 healthy sea bream. The strain was grown in the SSN-1 cell line and the viral RNA was purified using $200 \mu \mathrm{l}$ of cell supernatant and the 'high pure viral nucleic acid' kit (Boehringer-Mannheim, Meylan, France). Primers F2 and R3 (Nishizawa et al. 1994) were used, as described above, for RT-PCR using the purified viral RNA as template. The same primers were also used for direct sequencing of the purified PCR product, using an ABI 373A automated sequencer (Perkin Elmer), and the ABI Prism dye terminator cycle sequencing ready reaction kit (Perkin Elmer), accord- 
ing to the manufacturer's instructions. Sequence comparison with other nodavirus strains was performed using Multalin (Corpet 1988).

Experimental groups and infection trials. The fish used in the 2 infection experiments were obtained from nodavirus-free farms which were regularly checked for this virus by analysis on SSN-1 cells and by PCR. After arriving in the laboratory, the fish were acclimated to $25^{\circ} \mathrm{C} \pm 2{ }^{\circ} \mathrm{C}$ for at least $5 \mathrm{~d}$. Nodavirus (strain $\mathrm{V}_{113}$ ) isolated from 1 sea bream was used after a third passage on SSN-1 to infect the fish. In both experiments, mock-infected control groups were handled in the same way as infected ones, but non-infectious supernatant from SSN-1 cells was used instead of nodavirus suspension. During the entire experiment, the temperature of seawater was regulated at $25^{\circ} \mathrm{C} \pm$ $2^{\circ} \mathrm{C}$ and the fish fed a commercial diet ad libitum.

First experiment: Two groups of 10 sea bass (mean weight $15 \mathrm{~g}$ ) and 2 groups of 40 juvenile sea bream (mean weight $2 \mathrm{~g}$ ) were distributed into four $50 \mathrm{l}$ tanks. Two additional groups of 20 sea bream (which were younger since it was only $1 \mathrm{wk}$ after starting a commercial diet) were put in floating cages in the 2 tanks of juvenile sea bream previously described.

Ten sea bass and 40 juvenile sea bream received an intramuscular (IM) injection of about $2 \times 10^{6} \mathrm{TCID}_{50}$ of nodavirus (strain $\mathrm{V}_{113}$ ) isolated from sea bream in a volume of 50 or $25 \mu l$, respectively. The younger sea bream were immersed for $2 \mathrm{~h}$ in $500 \mathrm{ml}$ of aerated seawater containing about $2 \times 10^{6} \mathrm{TCID}_{50} \mathrm{ml}^{-1}$ of the same nodavirus strain. Afterwards, they were placed in a floating cage in the tank containing the injected juveniles.

The mortality was recorded daily and a virological analysis performed by cell culture on brain and eyes of dead sea bass and on the head of sea bream from all groups sampled 17 and $50 \mathrm{~d}$ post-infection.

Second experiment: Two hundred sea bream (mean weight $4.4 \mathrm{~g}$ ), kept in a $200 \mathrm{l}$ seawater tank, were IM injected with $50 \mu \mathrm{l}$ of SSN-1 supernatant containing about $2 \times 10^{6} \mathrm{TCID}_{50}$ of nodavirus $\mathrm{V}_{113}$. Two days later, after the tank had been emptied twice a day to eliminate any virus which may exude from the point of injection, a floating cage containing 70 nodavirus free sea bass (mean weight $2 \mathrm{~g}$ ) was placed in the tank. At 4, 7, 11, 18 and $29 \mathrm{~d}$ after injection of the virus into the sea bream, 5 sea bream and 10 sea bass were sampled for virological analysis. Tissue from one-half of a brain and one eye from each fish were pooled and the presence of nodavirus was assayed using SSN-1 cells. The other half of the brain and the other eye were pooled and the presence of nodavirus RNA was examined by RT-PCR. The sea bream were tested individually while half a brain and one eye from sea bass were tested by pooling 2 fish.

In the mock-infected groups a virological analysis was performed only on Day 4 and Day 29.

\section{RESULTS}

\section{Virus isolation and identification}

As generally observed with nodavirus isolated from sea bass, no CPE resulted from the inoculation of SSN1 cells with extracts of brain and eyes from the apparently healthy farmed sea bream. Some round cells forming clusters were observed in some wells, but the cell monolayer remained intact after $7 \mathrm{~d}$ of incubation when the second passage was performed. No additional change in the cells was observed compared to the control cells during this second passage. After $5 \mathrm{~d}$ of second passage, the supernatants of the wells were saved and the cells fixed for IFAT. The presence of nodavirus was clearly detected in 4 sea bream out of 10 examined by using a rabbit polyclonal nodavirus specific antiserum (Fig. 1).

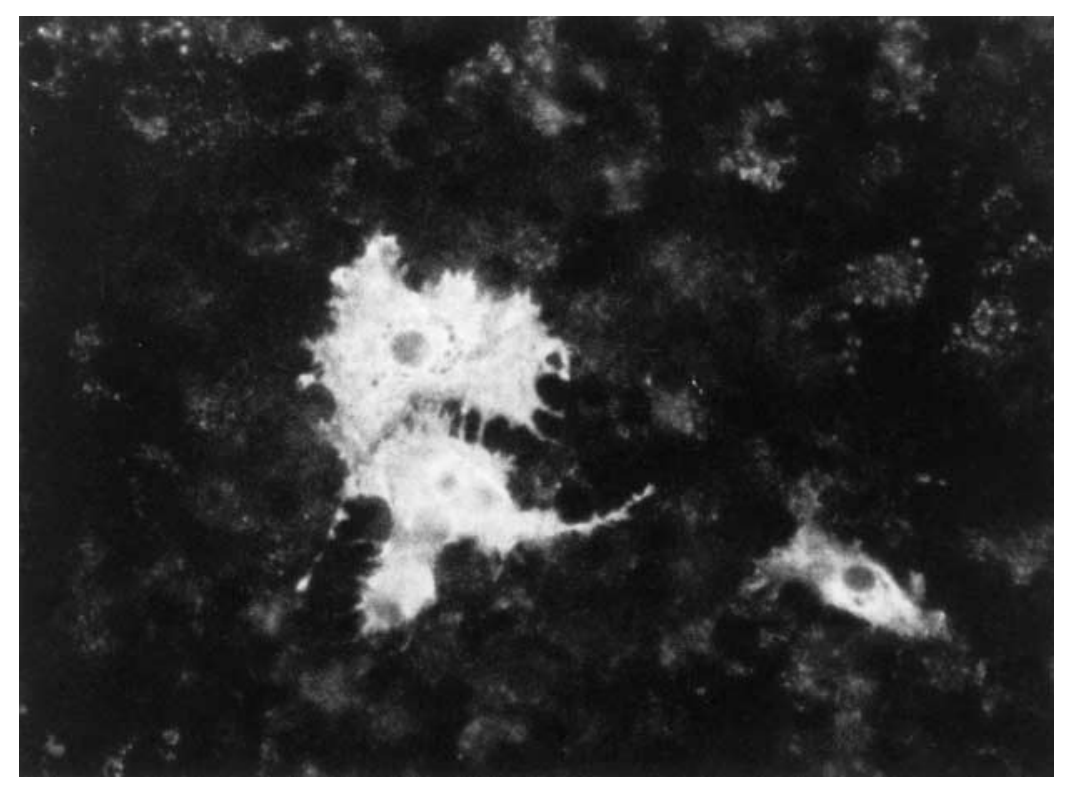

Fig. 1. SSN-1 cells infected with the nodavirus strain $\left(\mathrm{V}_{113}\right)$ from sea bream. After the cells had been incubated for $5 \mathrm{~d}$ at $24^{\circ} \mathrm{C}$, indirect immunofluorescence antibody test (IFAT) was performed with a rabbit antiserum against nodavirus. Fluorescent labelling of the infected cells was observed which also depicted intracytoplasmic vacuoles 
Individual RT-PCR reactions were performed using total RNA extracted from the eyes and the brains of the same fish that were examined for virus isolation. All samples were found to be negative by this technique; the expected band of 420 base pairs was not observed with these samples, indicating that the quantity of nodavirus was probably below the detection level of this method. Therefore, the nested RT-PCR method was performed in order to improve the sensitivity of the detection. Using this assay, nodavirus-specific signals were observed in several samples: 2 out of 10 eye samples and 6 out of 10 brain samples were positive. Fish that were positive for eye samples were also positive for brain samples. Control reactions which did not contain template were negative.

In order to confirm that the isolated virus was indeed a nodavirus, RT-PCR was performed again with viral RNA isolated from the $\mathrm{V}_{113}$-infected SSN-1 cell culture using the F2 and R3 primers. Analysis of the PCR products by agarose gel electrophoresis revealed the presence of the expected band of approximately 420 base pairs. Sequence determination of the PCR product indicated that it was the result of the amplification of the T4 region of the nodavirus capsid protein gene. Furthermore, a sequence comparison with other viral strains isolated from sea bass of the same farm $\left(\mathrm{V}_{26}, \mathrm{~W}_{80}\right)$ showed that all capsid sequences shared $100 \%$ identity (Fig. 2). $V_{113}$ depicted $80 \%$ identity with DLEV, another sea bass nodavirus strain.

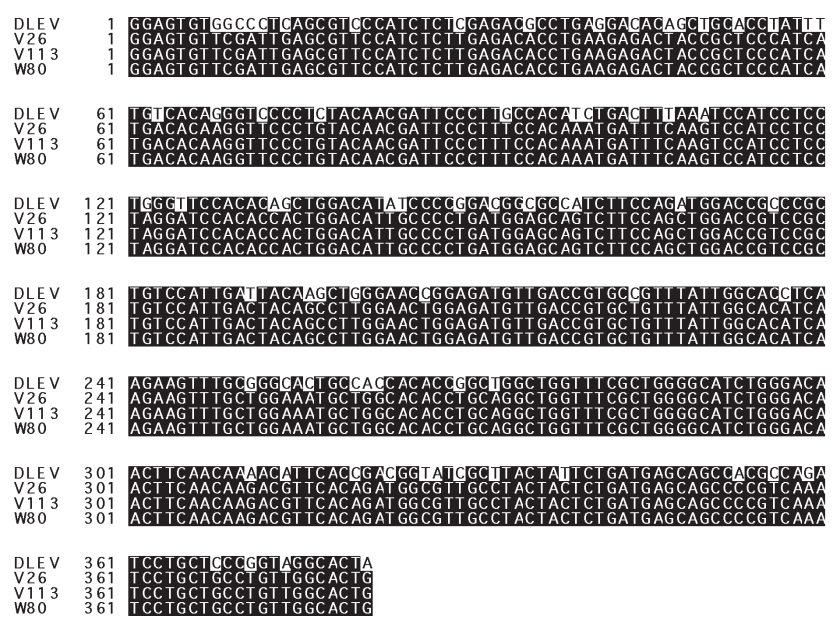

Fig. 2. Multiple alignment of the T4 region of the capsid protein gene from several fish nodavirus isolates. The region shown encompasses nucleotides 608 to 988 from the start codon. Sequences were obtained as described in 'Materials and methods'. Isolates were $\mathrm{V}_{26}$ (sea bass, 1996), $\mathrm{V}_{113}$ (sea bream, 1997), and $\mathrm{W}_{80}$ (sea bass, 1998), which were all sampled in the same fish farm. The sequence of the DLEV isolate (sea bass, 1992) was obtained from GenBank (accession no.: U39876, Delsert et al. 1997)

\section{Infection trials with nodavirus}

First experiment

Sea bass: In the group of 10 sea bass infected with the nodavirus strain $\left(\mathrm{V}_{113}\right)$, the first signs of VER appeared $4 \mathrm{~d}$ after IM injection.

The fish had dark coloration and displayed an erratic swimming behaviour. They began to die on Day 6, and by Day 10, all of them were dead. A virological control testing a pool of brain and eye tissue from 4 fish that died on Day 7 showed a viral concentration greater than $2 \times 10^{7} \mathrm{TCID}_{50}{ }^{-1} \mathrm{~g}$ of organ tissue. No mortality occurred in the control group which was maintained for $1 \mathrm{mo}$ at $25^{\circ} \mathrm{C}$.

Sea bream: During the $50 \mathrm{~d}$ of the experiment, no specific clinical sign of nodavirosis was observed in the 2 groups of infected sea bream.

In the juvenile and in the younger groups, 2 and 3 fish died, respectively, while in the corresponding control groups, 8 and 5 died. No virological analysis was performed on those dead fish due to the lack of intact tissue for sampling, as the eyes and brain were absent due to cannibalism.

A virological analysis performed $17 \mathrm{~d}$ post-infection revealed the presence of nodavirus in the head of 3 out of 5 fish examined in the juvenile group and 1 out of 5 in the younger fish.

At the end of the experiment, none of the 5 juvenile fish in the infected group were found positive for nodavirus, but 1 out of 5 of the younger fish was positive. The mock-infected fish remained negative in the 2 analyses.

\section{Second experiment}

No mortality and no signs of VER were observed in the 2 species during the $1 \mathrm{mo}$ of the experiment.

All of the pools of sea bream brain and eye analysed on Days 4 and 7 post-infection were found to be positive for nodavirus on SSN-1 (Table 1) with viral concentrations ranging from $1 \times 10^{3}$ to $1 \times 10^{5}$ TCID $_{50} \mathrm{~g}^{-1}$ as estimated by the end point-titration using IFAT on SSN-1. Four and 5 pools, out of 5 respectively, were found to be positive by PCR on Days 4 and 7 .

On Days 11 and 18 post-infection, 3 and 4 out of 5 pools of sea bream organs were positive by RT-PCR. Among the PCR-positive samples, 2 pools out of 5 were still positive on SSN-1. The viral concentrations were a bit lower than previously observed, reaching $1 \times 10^{4}$ and $1 \times 10^{3} \mathrm{TCID}_{50} \mathrm{~g}^{-1}$, respectively. On Day 29 postinfection 4 out of 5 pools of sea bream organs were PCR-positive, whereas only 1 sea bream sample was tested positive by inoculation on SSN-1 cells, with a low concentration of virus $\left(1 \times 10^{2} \mathrm{TCID}_{50} \mathrm{~g}^{-1}\right)$. 
Table 1. Number of fish (or pools of 2 fish), out of 5 , found nodavirus-positive by IFAT on SSN-1 cells or by PCR. The sea bass were sampled from a floating cage placed in the tank containing the sea bream $2 \mathrm{~d}$ after the latter fish had been injected (IM) with nodavirus $\mathrm{V}_{113}$

\begin{tabular}{|lcccccccccccc|}
\hline & \multicolumn{4}{c}{$\begin{array}{c}\text { Sea bream } \\
(5 \text { individual })\end{array}$} & & \multicolumn{5}{c|}{$\begin{array}{c}\text { Sea bass } \\
(5 \text { pools of } 2 \text { fish })\end{array}$} \\
\hline $\begin{array}{l}\text { Days post- } \\
\text { infection }\end{array}$ & 4 & 7 & 11 & 18 & 29 & 2 & 5 & 9 & 16 & 27 \\
SSN-1 & $5+$ & $5+$ & $2+$ & $2+$ & $1+$ & $0+$ & $0+$ & $2+$ & $2+$ & $0+$ \\
RT-PCR & $4+$ & $5+$ & $3+$ & $4+$ & $4+$ & $0+$ & $0+$ & $1+$ & $0+$ & $0+$ \\
\hline
\end{tabular}

In the group of sea bass, the first detection of nodavirus occurred $9 \mathrm{~d}$ after the fish were placed in contact with the infected sea bream. Two pools of eye and brain tissue were found to be positive out of 5 examined (viral concentrations of $1 \times 10^{3} \mathrm{TCID}_{50} \mathrm{~g}^{-1}$ ). One of the cell culture positive sample was also PCR-positive, whereas the other remained PCR negative. The same results were obtained on Day 16, with the exception that the PCR samples remained negative. On Day 27, no virus was evidenced by cell culture with the 5 pools, and RNA extracts were negative by RT-PCR. The mock-infected control in the 2 species remained nodavirus negative.

\section{DISCUSSION}

In the case reported here, no overt VER was observed in a cage of sea bream farmed in proximity to sea bass which were suffering an epizootic of this disease. Nevertheless, by using SSN-1 cell culture, a nodavirus was isolated from 4 sea bream out of 10 sampled from the cage. It is likely that the infection of the sea bream resulted from the excretion of viral particles into the environment by diseased sea bass. This is strongly supported by the fact that the viral capsid protein sequence of the nodavirus strains isolated from both species had $100 \%$ identity in the nucleotide sequence homology. All nodavirus sequences retrieved here were identical but different from the DLEV isolate sequence (Delsert et al. 1997) which had previously been shown to be genetically distinct from $\mathrm{V}_{26}$ (Thiéry et al. 1999a).

It has already been observed that sea bream do not seem to suffer from VER, even when these fish are raised in the vicinity of sea bass undergoing epizootics of this disease (Sweetman et al. 1996, J. C. Raymond unpubl. obs.). Only one paper has described nodavirus-like particles in the retina of sea bream larvae with high mortality associated with clinical signs similar to those described in sea bass suffering VER. However, no signal could be detected on sections of fish by in situ hybridisation with a fish nodavirus-specific probe (Comps \& Raymond 1996).
Thus, to our knowledge, this is the first report of successful isolation and characterisation of a nodavirus from asymptomatic sea bream. Then, it seems that even if nodavirus could infect sea bream, this virus is not pathogenic for this particular species of fish.

A nodavirus carrier state in sea bream has been demonstrated during the 2 different experiments reported here. In both experiments, a significant proportion of experimentally infected fish were found to be nodavirus-positive, whether by cell culture and/or RT-PCR, even after several weeks post-infection (up to $50 \mathrm{~d}$ post-infection in the first experiment). However, it is worth noting that the proportion of positive fish decreased with time when cell culture was used to assay the presence of nodavirus, whereas the RT-PCR method could still detect a high proportion of positive fish (4 positive pools out of 5 on Day 29, second experiment). On the other hand, the intensity of the PCR signals, on an agarose gel stained with ethidium bromide, was always low in the sea bream samples (not shown). Taken together, these observations could indicate that nodavirus replication was low in this host.

The lack of pathogenicity to sea bream could be due to a loss of virulence during passages on cell culture. However, results of the experimental infection of sea bass using the same strain indicated that it remained highly pathogenic for sea bass, as none of the 10 injected fish survived when the experiment was conducted at $25^{\circ} \mathrm{C}$, which was the temperature previously used for experimental transmission of VER to sea bass (Péducasse et al. 1999). Furthermore, a previous experiment with sea bream $(8 \mathrm{~g})$ injected with a pathogenic nodavirus strain isolated from sea bass had given similar results at this temperature, and no lesions were observed in the brain and retina of the sea bream fish sampled $2 \mathrm{wk}$ after infection (J. Castric unpubl. results).

The role of the sea bream as a reservoir of nodavirus to infect susceptible species has also been experimentally demonstrated. Nodavirus was recovered from sea bass by cell culture at 9 and $16 \mathrm{~d}$ after a floating cage containing healthy fish was placed in a contaminated sea bream population. Thus, it is likely that the nodavirus was excreted by infected sea bream and spread to the sea bass via the water, as cannibalism was excluded because of the cage separating the 2 species. However, no signs of VER were noticed among the sea bass, which could be probably due to a low infectious dose excreted into the water by contaminated sea bream. Besides, it was shown previously that transmission of VER to juvenile sea bass by bath challenge was less efficient than by the intramuscular route (Péducasse et al. 1999).

The results of our experiments indicate that sea bream Sparus aurata is susceptible to infection by nodavirus but refractory to the disease in our experimen- 
tal conditions. Larvae of Pagrus major, another sparidae, were also demonstrated to be refractory to VNN after exposure to water containing purified virus (Arimoto et al. 1993). Thus, at the present time, species of sparidae family do not appear to be susceptible to VER, as demonstrated from transmission studies and from field observations. On the other hand, the fact that the nodavirus strain described in the present study does not seem to be pathogenic to sea bream does not exclude the hypothesis that it could adapt to this species, or that other nodavirus strains could induce VER in this species. Further work is needed to investigate these points.

Finally, it should be pointed out that nodavirus healthy carrier sea bream could exist in aquaculture facilities and that it could be a threat for other susceptible species such as sea bass. These observations should be considered in aquaculture management plans, especially when both species are reared in the same facilities.

Acknowledgements. The authors are grateful to 'Ferme Marine du Douhet' and IFREMER Brest for having supplied the sea bream and sea bass used in the experimental assays. They kindly thank Dr Caroline O'Farrell from the Western Fish Research Center of Seattle for her helpful comments on the manuscript. This work was supported by the FAIR Program PL98-4036 granted by the EEC.

\section{LITERATURE CITED}

Arimoto M, Mushiake K, Mizuta Y, Nakai T, Muroga K, Furusawa I (1992) Detection of Striped Jack Nervous Necrosis Virus (JSNNV) by enzyme-linked immunosorbent assay (ELISA). Gyobyo Kenkyu 27:191-195

Arimoto M, Mori K, Nakai T, Muroga K, Furusawa I (1993) Pathogenicity of the causative agent of viral nervous necrosis disease in striped jack, Pseudocaranx dentex (Block \& Schneider). J Fish Dis 16:461-469

Chomczynski P, Sacchi N (1987) Single-step method of RNA isolation by acid guanidinium-thiocyanate-phenol-chloroform extraction. Anal Biochem 162:156-159

Comps M, Raymond JC (1996) Virus-like particles in the retina of the seabream, Sparus aurata. Bull Eur Assoc Fish Pathol 16:161-163

Comps M, Pépin JF, Bonami JR (1994) Purification and characterization of two fish encephalitis viruses (FEV) infecting Lates calcarifer and Dicentrarchus labrax. Aquaculture 123:1-10

Corpet F (1988) Multiple sequence alignment with hierarchical clustering. Nucleic Acids Res 16: 10881-10890

Delsert C, Morin N, Comps M (1997) A fish encephalitis virus that differs from other nodaviruses by its capsid protein processing. Arch Virol 142:2359-2371

Frerichs GN, Rodger HD, Peric Z (1996) Cell culture isolation of piscine neuropathy nodavirus from juvenile seabass, Dicentrarchus labrax. J Gen Virol 77:2067-2071

Glazebrook JS, Heasman MP, de Beer SW (1990) Picorna-like viral particles associated with mass mortalities in larval barramundi, Lates calcarifer Bloch. J Fish Dis 13:245-249

Grotmol S, Bergh O, Totland GK (1999) Transmission of viral encephalopathy and retinopathy (VER) to yolk-sac larvae of the Atlantic halibut Hippoglossus hippoglossus: occur- rence of nodavirus in various organs and a possible route of infection. Dis Aquat Org 36:95-106

Kärber G (1931) Beitrag zur kollektiven Behandlung pharmakologischer Reihenversuche. Arch Exp Pathol Pharm 162:480-483

Le Breton A, Abela M, Brinck-Iversen J (1997a) Viral Nervous Necrosis of seabass Dicentrarchus labrax L.: epidemiological data and prophylactic guidelines. Abstracts book, VIIIth International Conference 'Diseases of Fish and Shellfish'. EAFP, Edinburgh, 14-19 September, p 50

Le Breton A, Grisez L, Sweetman J, Ollevier F (1997b) Viral nervous necrosis (VNN) associated with mass mortalities in cage-reared seabass, Dicentrarchus labrax (L.). J Fish Dis 20:145-151

Mori K, Nakai T, Muroga K, Arimoto M, Mushiake K, Furusawa I (1992) Properties of a new virus belonging to nodaviridae found in larval striped jack (Pseudocaranx dentex) with nervous necrosis. Virology 187:368-371

Munday BL, Nakai T (1997) Special topic review: nodavirus as pathogens in larval and juvenile marine finfish. World $\mathrm{J}$ Microbiol Biotechnol 13:375-381

Muroga K (1995) Viral and bacterial diseases in larval and juvenile marine fish and shellfish: a review. Fish Pathol 30:71-85

Mushiake K, Nishizawa T, Nakai T, Furusawa I, Muroga K (1994) Control of VNN in striped jack: selection of spawners based on the detection of SJNNV gene by polymerase chain reaction (PCR). Fish Pathol 29:177-182

Nakai T, Mori T, Nishizawa T, Muroga K (1995) Viral nervous necrosis of larval and juvenile marine fish. Proceedings of the International Symposium on Biotechnology Applications in Aquaculture. Asian Fish Soc (Spec Publ) 10:147-152

Nguyen HD, Nakai T, Muroga K (1996) Progression of striped jack nervous necrosis virus (SJNNV) infection in naturally and experimentally infected striped jack Pseudocaranx dentex larvae. Dis Aquat Org 24:99-105

Nishizawa T, Mori K, Nakai T, Furuzawa I, Muroga K (1994) Polymerase chain reaction (PCR) amplification of RNA of striped jack nervous necrosis virus (SJNNV). Dis Aquat Org 18:103-107

Nishizawa T, Muroga K, Arimoto M (1996) Failure of the polymerase chain reaction (PCR) method to detect striped jack nervous necrosis virus (SJNNV) in striped jack Pseudocaranx dentex selected as spawners. J Aquat Anim Health 8:332-334

Péducasse S, Castric J, Thiéry R, Jeffroy J, Le Ven A, Baudin Laurencin F (1999) Comparative study of viral encephalopathy and retinopathy in juvenile seabass Dicentrarchus labrax infected in different ways. Dis Aquat Org 36:11-20

Skliris GP, Richards RH (1999). Nodavirus isolated from infected tilapia (Oreochromis mossambicus). J Fish Dis 22: $315-318$

Sweetman E, Sweetman J, Le Breton A, Grisez L (1996) Nodavirus: a review of the findings of the XIV/Noda/95 investigation. Seabass and seabream culture: problems and prospects. Handbook of contributions and short communications, Verona, Italy, October 16-18, p 87-101

Tanaka S, Aoki H, Nakai T (1998) Pathogenicity of the nodavirus detected from diseased sevenband grouper Epinephelus septemfasciatus. Fish Pathol 33:31-36

Thiéry R, Arnauld C, Delsert C (1999a) Two different isolates of sea bass (Dicentrarchus labrax) Nervous Necrosis Virus with distinct genomes. J Fish Dis 22:201-207

Thiéry R, Raymond JC, Castric J (1999b) Natural outbreak of viral encephalopathy and retinopathy in juvenile seabass, Dicentrarchus labrax: study by nested reverse transcriptase-polymerase chain reaction. Virus Res 63:1-7 